\title{
Impact of Some Soil Amendments on Properties and Productivity of Salt Affected Soils at Kafr El-Sheikh Governorate
}

\author{
M. M. Amer* and I. M. Hashem ${ }^{* * *}$ \\ * Soils Improvement and Conservation Res. Department, Soils, Water and Environment \\ Res. Institute and ${ }^{* *}$ Rice Res. \& Training Center, Sakha, Kafr El-Sheikh, Field Crop \\ Res. Institute, Agric. Res. Center, Giza, Egypt.
}

\begin{abstract}
$\mathbf{T}$ WO FIELD trials were conducted in salt affected soils at special farm Mars El-Gaml village, Kafr El-Sheikh Governorate, Egypt to study the effects of amending soils with gypsum, compost, ammonia injection and subsoiling on some soil physio-chemical properties as well as the outcome yields of barley (winter 2016/2017) and rice (summer 2017). Seven treatments were tested to attain this aim using a complete randomized block design (CRBD) with three replicates. The results showed that improving soil chemical properties such as soil salinity and soidicity took place through amending soils with gypsum requirements (SGR) combined with $4 \mathrm{Mg}$. from compost fed. -1 and subsoiling in both seasons ( 1 feddan $=0.42 \mathrm{ha}$ ). Such treatments recorded a positive effect on soil $\mathrm{Ca} / \mathrm{Mg}$ ratio in root zone $(0-60 \mathrm{~cm})$ in both seasons. It could be observed that the application of SGR combined with compost and subsoiling was superior to other treatments in decreasing of the soil bulk density and increment both of the soil porosity and soil infiltration rate. Yield of barely and rice were highly significantly increased and recorded highest values due to application of gypsum combined with ammonia and subsoiling. Economic efficiency recorded the highest values due to application of SGR and ammonia injection with subsoiling in both seasons. Consequently, application of SGR with ammonia and subsoiling treatments could be used economically to improve the yield of barely and rice. Some physio-chemical properties of salt affected were improved by application of SGR combined with compost and subsoiling at Kafr El-Sheikh Governorate.
\end{abstract}

Keywords: Ammonia injection, Subsoiling, Salt affected soils, Soil amendments, Yield.

\section{Introduction}

Salt affected soils represent about $30 \%$ from the total cultivated area in Egypt (FAO 2005) and $37 \%$ of the total cultivated soils in Nile Delta, while the North Delta contains the highest area of saline and saline-sodic soils (46\%). Poor drainage in addition to reuse of saline drainage water supports the buildup of salinity and sodicity (Negm 2016). Saline, sodic, or saline/sodic soils are originated mainly in the semi-arid areas where the evaporation rate exceeds precipitation (Qadir et al., 2008). The degradation due to salinization, intrusion of seawater and water logging are the current potential hazard in the irrigated land. It's could be considered as an important issue in the agricultural security program (AbdelFattah, 2012). It has been known that sodium and magnesium has a negative effect on soil physical properties when its concentration is relatively high compared to calcium. The slow drawdown rate of the excess water through soil profile after irrigation indicated that the tile drainage system in the Mars El-Gaml, Kafr El-Sheikh Governorate area is not efficient and/or the soil is compacted due to unfavorable chemical and physical (Amer et al., 2017). The infiltration rate can be restricted by poor soil management (Haghnazari et al., 2015). Moukhtar et al. (2003) reported that saline groundwater is a permanent source of soil salinzation that causes poor productivity in the irrigated areas. It is also stated that, good drainage efficiencies and proper soil management are important factors to improve soil characteristics. Rice is reclaiming crop for saline and salinesodic soils. Rice is sensitive to salinity at different growth stages (Zeng, 2004; Moradi and Ismail, $2007)$, leading to a reduction in crop yield of more than $50 \%$ when exposed to $6.65 \mathrm{dS} \mathrm{m}^{-1}$ electrical conductivity (ECe) in soil (Zeng and Shannon,

*Corresponding author.: E-mail:megahedamer3@gmail.com

DOI : 10.21608 /ejss.2018.2356.1148

(C)2018 National Information and Documentation Center (NIDOC) 
2000). The threshold of average root zone critical salinity values for barley growth is $8 \mathrm{dSm}^{-1}$ and slope $5 \% / \mathrm{dS} \mathrm{m}^{-1}$ and $3 \mathrm{dS} \mathrm{m}^{-1}$ and slope $12 \% / \mathrm{dSm}^{-}$ ${ }^{1}$ for rice (Rhoades et al., 1992). Winter barley is the crop of wheat soils of poorer quality. In Egypt, grain yield of barely varied between 1.8 ton fed $^{-1}$ to $2.16 \mathrm{Mg} \mathrm{fed}^{-1}$ under normal clay soil. Horneck et al. (2007) reported that the accumulation of excessive salt in irrigated soils reduce crop yields, reduce the effectiveness of irrigation, ruin soil structure and affect other soil properties. In addition, rice which is grown under submerged conditions helps to leach down soluble salts up to a greater extent, and hence decrease ECe (Ghafoor et al., 2008). Managing salt affected soil is required during soil reclamation. The construction of mole $d$ rain is effective in decreasing of the soil salinity, sodicity and bulk density El-Henawy et al. (2016) and it can increase soil infiltration rates Aiad (2014). Also, gypsum has become an efficient soil amendment to reclaim sodic soils of poor aggregation or soil structure (Fisher and Madeline, 2011). Application of gypsum increases of soluble $\mathrm{Ca}^{2+}$ in soil solution to substitute the adsorbed sodium, hence overcome the dispersion effects of $\mathrm{Na}^{+}$and improve the soil structure in the dispersed soils. (Shainberg et al., 1988). The decaying organic matter increases soil $\mathrm{CO}_{2}$ concentrations and releases $\mathrm{H}^{+}$when it dissolves in water. The released $\mathrm{H}^{+}$ enhances $\mathrm{CaCO}_{3}$ dissolution and liberates more calcium for sodium exchange (Ghafoor et al,. 2008). However, the addition of organic matter in conjunction with gypsum has been successful in reducing adverse soil properties associated with sodic soils Abdel-Fattah and Merwad (2016) and Saied et al. (2017). The application of compost accelerated sodium leaching and reduced EC, which increased water-holding capacity and soil aggregate stability (Tejada et al., 2006). Decreased soil dispersion and reduced EC more effectively than those attained when amending soils with gypsum solely (Vance et al. 1998), beside of improving the chemical properties $(\mathrm{EC}, \mathrm{pH}$ and SAR) of the saline sodic soil to the desired levels (Ghulam et al. 2011).while the dispersion of clays from soils was increased when $\mathrm{Ca} / \mathrm{Mg}$ ratios in the percolating solutions were below unity with an SAR1:5 >3. (Bardhan et al., 2007) while the productivity of soil was higher when $\mathrm{Ca} / \mathrm{Mg}$ ratio on the soil exchange complex was 3.2:1 (Ansari et al., 2010). High $\mathrm{Mg}^{2+}$ in soils creates big blocks that are hard to be broken down and thus reduces $\mathrm{K}$ and $\mathrm{N}$ efficiency(Genever, 2010). Moreover,
Mg induced K deficiency (Hannan, 2011).On the other hand, Dontsova and Norton (2001) observed that availability of $\mathrm{K}$ and ammonium can also be affected by a soil's preference for $\mathrm{Ca}^{2+}$. They suggested further study is needed to explore how distribution of $\mathrm{K}$ between solution, exchangeable and non-exchangeable phases is influenced by the $\mathrm{Ca} / \mathrm{Mg}$ ratio. Anhydrous ammonia is one of the most efficient and widely used as source of nitrogen for plant growth. The advantages of ammonia relatively easy application and ready availability have led to its increased use as a fertilizer. In soil, ammonia reacts with water to form the ammonium $\left(\mathrm{NH}_{4}^{+}\right)$ion, which is held on clay and organic matter. Anhydrous ammonia increased gross income, net income, benefit / costs ratio and profitability of rice. Osman et al. (2013). The current study aims to evaluate the effect of some soil amendments, ammonia injection and subsoiling on improving some physio-chemical properties and productivity of salt affected soils at Kafr El-Sheikh Governorate..

\section{Materials And Methods}

Two field trials were conducted in salt affected soil at Mares El-Gamal village, Kafr El-Sheikh Governorate, North Nile Delta, Egypt, during winter (2016/2017) and summer (2017) to study the impact of some soil amendments, ammonia injection and subsoiling on soil properties and productivity of barely and rice.. The location is situated at $31^{\circ} 12^{\prime} 43.00^{\prime \prime} \mathrm{N}$ and $30^{\circ} 59^{\prime} 40.00^{\prime}$ " E. The salinity of irrigation water was $0.5 \mathrm{dSm}^{-1}$ and drainage water salinity was $4.64 \mathrm{dS} \mathrm{m}^{-1}$. The area is under subsurface drainage system installed at a depth of approximately $2.0 \mathrm{~m}$ with $25 \mathrm{~m}$ laterals spacing. The water table in this area was $80 \mathrm{~cm}$ below the ground surface. The recommended agricultural practices were followed during both seasons. Chemical and physical characteristics of the experimental sites prior to each growing season are presented in Tables 1 and 2. Chemical characteristics of different compost plant residues are shown in Table 3. The experimental plot was $200 \mathrm{~m}^{2}$ and treatments were arranged in a complete randomized block design (CRBD) with three replicates as follows:

1- Check treatment

2- Gypsum (G)

3- Gypsum + Ammonia (A)

4- Gypsum + Compost (C)

5- Gypsum + Subsoiling (S)

6- Gypsum + Subsoiling + Ammonia

7- Gypsum + Compost + Subsoiling 


\begin{tabular}{|c|c|c|c|c|c|c|}
\hline \multirow{12}{*}{ 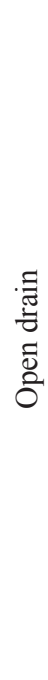 } & \multicolumn{5}{|c|}{ Main Irrigation channel } & \\
\hline & \multirow{10}{*}{ 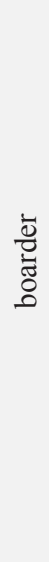 } & \multicolumn{3}{|c|}{ boarder $(1 \times 60)$ meter } & \multirow{11}{*}{ 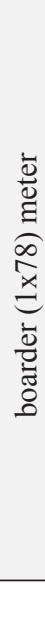 } & \multirow{11}{*}{ 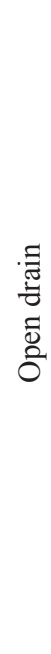 } \\
\hline & & $\begin{array}{l}\text { Check treatment }(10 \times 20) \\
\text { meter }\end{array}$ & $\begin{array}{l}\text { Check treatment }(10 \times 20) \\
\text { meter }\end{array}$ & $\begin{array}{l}\text { Check treatment }(10 \times 20) \\
\text { meter }\end{array}$ & & \\
\hline & & boarder $(1 \times 20)$ meter & boarder $(1 \times 20)$ meter & boarder $(1 \times 20)$ meter & & \\
\hline & & $\mathrm{G}+\mathrm{S}+\mathrm{C}$ & $\mathrm{G}+\mathrm{S}+\mathrm{C}$ & $\mathrm{G}+\mathrm{S}+\mathrm{C}$ & & \\
\hline & & & & & & \\
\hline & & G + Ammonia (A) & G + Ammonia (A) & $\mathrm{G}+\mathrm{Ammonia}(\mathrm{A})$ & & \\
\hline & & $\mathrm{G}+$ Compost $(\mathrm{C})$ & $\mathrm{G}+$ Compost $(\mathrm{C})$ & $\mathrm{G}+$ Compost $(\mathrm{C})$ & & \\
\hline & & $\mathrm{G}+$ Subsoiling $(\mathrm{S})$ & $\mathrm{G}+$ Subsoiling $(\mathrm{S})$ & $\mathrm{G}+$ Subsoiling $(\mathrm{S})$ & & \\
\hline & & Gypsum (G) & Gypsum (G) & Gypsum (G) & & \\
\hline & & $\mathrm{G}+\mathrm{S}+\mathrm{A}$ & $\mathrm{G}+\mathrm{S}+\mathrm{A}$ & $\mathrm{G}+\mathrm{S}+\mathrm{A}$ & & \\
\hline & \multicolumn{4}{|c|}{ Open drain } & & \\
\hline
\end{tabular}

Fig.1. Layout of the experiment

TABLE 1. Soil chemical properties of the experimental site before treatments.

\begin{tabular}{|c|c|c|c|c|c|c|c|c|c|c|c|c|c|c|}
\hline \multirow{2}{*}{ 营 总 } & \multirow{2}{*}{$\overline{\bar{\theta}}{ }^{*}$} & \multirow{2}{*}{ 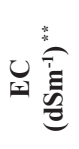 } & \multirow{2}{*}{ 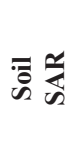 } & \multirow{2}{*}{ 包 } & \multicolumn{4}{|c|}{$\begin{array}{l}\text { Soluble cations } \\
\left(\mathrm{mmol}_{\mathrm{c}} \mathbf{L}^{-1}\right)\end{array}$} & \multicolumn{3}{|c|}{$\begin{array}{l}\text { Soluble anions } \\
\left(\mathrm{mmol}_{\mathrm{c}} \mathbf{L}^{-1}\right)\end{array}$} & \multirow{2}{*}{ 它施 } & \multirow{2}{*}{ 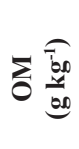 } & \multirow{2}{*}{ 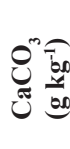 } \\
\hline & & & & & $\mathrm{Na}^{+}$ & $\mathbf{K}^{+}$ & $\mathrm{Ca}^{2+}$ & $\mathrm{Mg}^{2+}$ & $\mathrm{HCO}^{3}$ & $\mathrm{Cl}^{-}$ & $\mathrm{SO}^{=}$ & & & \\
\hline $0-20$ & 7.95 & 10.76 & 16.3 & 23.07 & 70.6 & 0.8 & 16.1 & 21.2 & 5.5 & 49.4 & 53.8 & 31.5 & 9.41 & 3.21 \\
\hline $20-40$ & 8.13 & 11.79 & 17.1 & 24.14 & 77.1 & 0.9 & 17.6 & 23.2 & 5.8 & 54.0 & 59.0 & 30.8 & 9.1 & 2.64 \\
\hline $\begin{array}{l}40- \\
60\end{array}$ & 8.29 & 13.84 & 19.0 & 27.04 & 91.8 & 0.8 & 19.5 & 27.1 & 5.5 & 64.3 & 69.4 & 30.3 & 8.21 & 2.51 \\
\hline Mean & - & 12.13 & 17.5 & 24.75 & 79.8 & 0.8 & 17.7 & 23.8 & 5.6 & 55.9 & 60.8 & 30.87 & 8.91 & 2.79 \\
\hline
\end{tabular}

Where: *Soil pH was determined in soil water suspension $(1: 2.5), * *$ soil EC was determined in saturated soil paste extract, SAR, ESP, $\mathrm{CEC}, \mathrm{OM}$ and $\mathrm{CaCo}_{3}$ represents sodium adsorption ratio, exchangeable sodium percentage, cation exchange capacity, organic matter and total calcium carbonate, respectively.

TABLE 2. Soil physical characteristics of the experimental site before treatments

\begin{tabular}{|c|c|c|c|c|c|c|c|c|c|c|}
\hline $\begin{array}{c}\text { Depth } \\
\text { (cm) }\end{array}$ & $\underset{(\mathbf{m} / \mathbf{d})}{\mathbf{K}}$ & $\begin{array}{c}\text { IR, } \\
(\mathrm{cm} / \mathrm{h})\end{array}$ & \multicolumn{4}{|c|}{ Soil moisture characteristics } & \multicolumn{4}{|c|}{ Particle size distribution (\%) } \\
\hline $20-40$ & 0.14 & 0.21 & 39.1 & 19.6 & 19.5 & 1.43 & 18.2 & 25.8 & 56.0 & Clayey \\
\hline $40-60$ & & & 39.5 & 19.7 & 19.8 & 1.44 & 18.2 & 24.2 & 57.6 & Clayey \\
\hline
\end{tabular}

Where: K, IR,FC, WP, AW, and BD represents hydraulic conductivity, infiltration rate, Field Capacity, wilting point, available water and bulk density, respectively.

TABLE 3. Some chemical characteristics of plant residuals compost

\begin{tabular}{ccccccccccc}
\hline $\begin{array}{c}\mathbf{E C} \\
\mathbf{d} S\end{array}$ & $\mathbf{p H}$ & $\begin{array}{c}\mathbf{C} / \mathbf{N} \\
\text { ratio } \\
\left.\mathbf{m}^{-1}\right)\end{array}$ & $\mathbf{O . M}$ & $\mathbf{N}$ & $\mathbf{P}$ & $\mathbf{K}$ & $\mathbf{F e}$ & $\mathbf{Z n}$ & $\mathbf{M n}$ & $\begin{array}{c}\text { Moisture } \\
\text { content }\end{array}$ \\
\hline 2.41 & 7.86 & $1 / 10$ & 31.5 & 2.12 & 0.70 & 1.25 & 135 & 48 & 126 & $\mathbf{( \mathbf { m g ~ k g } ^ { - 1 } )}$ \\
\hline
\end{tabular}

Before the winter season 2016/2017, subsoiling was conducted with $2 \mathrm{~m}$ spacing and $60 \mathrm{~cm}$ depth perpendicular to the open drainage. Open drain was used to collect the drainage water brought by subsoiling channels. All plots received $100 \mathrm{~kg}^{-1}$ mono-super phosphate $\left(15.5 \% \quad \mathrm{P}_{2} \mathrm{O}_{5}\right)$ and $50 \mathrm{~kg} \mathrm{Fed.}{ }^{-1}$ potassium sulphate, $\left(48 \% \mathrm{~K}_{2} \mathrm{O}\right)$ during tillage $(1$ feddan $=$ Egypt. J. Soil Sci., 58, No.2 (2018) 
$0.42 \mathrm{ha}$ ). The recommended $\mathrm{N}$ for barely ( $45 \mathrm{~kg}$ $\mathrm{Nfed}^{-1}$ ) crop was added to the plots didn't injected by ammonia or application of compost, while the recommended $\mathrm{N}$ for rice $\left(80 \mathrm{kgNFed} .^{-1}\right.$ ) was added to the plots didn't injected by ammonia and application (40 $\mathrm{kg} \mathrm{N}$ fed $^{-1}$ ) was added to the plots received compost. Ammonia injected (82\% N) was added as $\mathrm{N}$ recommended for barely and rice at $(10-15 \mathrm{~cm})$ depth from soil surface. Before the application of treatments, the area was ploughed with chisel plough and laser land dead leveled. Leaching requirements was calculated according $\mathrm{EC}_{\mathrm{w}}$ of irrigation and the permissible salinity of drainage water and applied with barley (about 20 $\%$ ). Gypsum was ploughed during soil tillage and followed by irrigation. Compost was added before planting of barely at a rate of 4 tonfed $^{-1}$, gypsum and compost were applied in the first season only. All soil treatments were applied one month before sowing to assure their complete decomposition except ammonia injection was done 5days before both of sowing of barely and transplanting of rice. Gypsum requirements were determined according to the methods described by U.S., salinity laboratory staff (FAO and IIASA, 2000), so 8.0 $\mathrm{Mg} \mathrm{fed}^{-1},(\mathrm{Mg}=$ metric tons; $1 \mathrm{fed}=0.42 \mathrm{ha})$ are sufficient to reduce the initial ESP from 24.75 to $10 \%$ for $30-\mathrm{cm}$ soil matrix as follows:

$$
\mathrm{GR}=\left(\mathrm{ESP}_{\mathrm{i}}-\mathrm{ESP}_{\mathrm{F}}\right) / 100 \times \mathrm{CEC} \times 1.72
$$

where GR: gypsum requirement $\left(\mathrm{Mgfed}^{-1}\right), \mathrm{ESP}_{\mathrm{i}}$ :

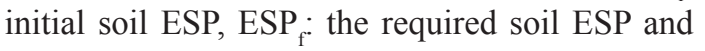
CEC: cation exchange capacity $\left(\mathrm{cmol}_{\mathrm{c}} \mathrm{kg}^{-1}\right)$.

Soil samples were collected from all plots before experiment and after the first and second seasons in three consecutive depths of $0-20$, 20-40 and 40-60 $\mathrm{cm}$ to monitor some physical and chemical characteristics. Salinity, sodium adsorption ratio and $\mathrm{Ca}^{2+} / \mathrm{Mg}^{2+}$ ratio was determined in saturated soil paste extract, exchangeable sodium was determined using ammonium chloride and measured by using flame photometer according to (Page et al., 1982). Soil bulk density and total porosity of the different layers of soil profile in all plots were measured using the core sampling technique as described by Campbell (1994). Infiltration rate was determined using double cylinder infiltrometer as described by Garcia (1978). Field capacity and wilting point were determined by using the pressure plate Egypt. J. Soil Sci., 58, No.2 (2018) extractor with regulated air pressure (Garicia, 1978). Barley (Hordeum vulgare L.), variety Giza 126 was sown on November $20^{\text {th }}, 2016$ and harvested on May, 5 ${ }^{\text {th }}, 2017$ while rice (Oryza sativa L.) variety Sakha101was sown May 10th, 2017 and transplanted after one month from growing seed in the nursery bed and harvested on September $30^{\text {th }}, 2017$. At physiological maturity growth stage, grain and straw yields of barley and rice $\left(\right.$ Mgfed. $^{-1}$ ) were determined in both seasons. All agricultural practices were carried out as recommended by the Ministry of Agriculture. Anhydrous ammonia was obtained from Soils, Water and Environment Research Institute (Ammonia Injection Unit, Kafr El-Sheikh).

\section{Economic evaluation}

Gross return (LE Fed. $^{-1}$ ), net return (LE Fed. ${ }^{1}$ ) and economic efficiency were used to run the economic evaluation.

\section{Statistical analysis}

The data were analyzed statistically by analysis of variance (ANOVA) using Cohort computer program according to Gomez and Gomez (1984).

\section{Results and Discussion}

\section{Soil chemical properties}

\section{Electrical conductivity (ECe)}

Table 4 and Fig. 2 revealed that the ECe in root zone $(0-60 \mathrm{~cm}$ depth) was highly significantly decreased by application of gypsum $(P \leq 0.01)$ after harvesting of barely and rice (9.22 and 6.84 $\mathrm{dSm}^{-1}$, respectively), where the corresponding reduction were $23.6 \%$ and $41.8 \%$, respectively as compared with check treatment (Fig.2). These results are in harmony with those obtained by Shainberg et al.(1988) and Fisher and Madeline (2011). Also, data showed that the ECe in root zone was highly significantly decreased due to application of gypsum combined with ammonia in the $1^{\text {st }}$ and $2^{\text {nd }}$ seasons $\left(9.25\right.$ and $6.79 \mathrm{dSm}^{-1}$, respectively) with reduction of $23.4 \%$ and 42.3 $\%$, respectively. However, ECe insignificantly affected by gypsum combined with ammonia as compared with gypsum only. These results may be due to gypsum plays a significant role in the providing a $\mathrm{Ca}^{2+}$ cation to replace the exchangeable $\mathrm{Na}^{+}$on the exchange positions and leaching it out into the groundwater (Sharma and Minhas, 2005). 
The data showed that application of compost had positive effect on ECe due to improving the soil physical properties; hence it led to remove $\mathrm{Na}^{+}$ fare from root zone. This finding is in agreement with Tejada et al. (2006) and Abdel-Fattah and Merwad (2016). On the other hand, application of gypsum with compost was more effective in improving the salt affected soils. Salinity level in soil amended by gypsum combined with compost was highly significantly decreased in root zone in both $1^{\text {st }}$ and $2^{\text {nd }}$ seasons ( 8.55 and $5.42 \mathrm{dSm}^{-1}$, respectively) with ECe reduction of $29.2 \%$ and $53.9 \%$, respectively as compared with check treatment. The obtained results seem to agree with Abdel-Fattah and Merwad (2016) and ElSanat et al. (2017). So, it could be observed that application of gypsum combined with compost was more effective than gypsum alone on salt leaching.

The subsoiling treatments were more effective on salt leaching, may be due to improvement of soil basic infiltration and leaching of the salts from the surfaces layers out to the drainage system (Aiad, 2014 and El-Henawy et al., 2016). Regarding to the effect of subsoiling combined with gypsum on soil salinity; the data referred to that the ECe values were highly significantly decreased due to gypsum and subsoiling with both crops (7.98 and $4.75 \mathrm{dSm}-1$, respectively), where the reductions of ECe were $33.9 \%$ and $59.6 \%$, respectively as compared with check treatment. The combined application of gypsum with subsoiling was more effective than gypsum only on leaching of the salts. These results showed obvious role of the subsoiling in improving of drainage efficiency and in sequence enhances salts leaching especially with gypsum application. These observations are in agreement with El-Sanat et al. (2017).

Also, data cleared that gypsum with subsoiling and ammonia injection had a highly significant effect on decreasing ECe after the 1st and 2nd seasons (7.89 and $4.72 \mathrm{dSm}-1$, respectively), whereas the reduction of ECe were $(34.6 \%$ and $59.6 \%$, respectively) as compared with check treatment.

Table 4 showed that the ECe was highly significant decreased due to application of gypsum with compost and subsoiling after the $1^{\text {st }}$ and $2^{\text {nd }}$ seasons (7.55 and $4.13 \mathrm{dS} \mathrm{m}^{-1}$, respectively), with reduction of $37.4 \%$ and $64.9 \%$, respectively as compared with check treatment. It could be observed that the soil salinity after rice crop were recorded lowest values as compared with after barely. These results may be due to during growth stages of rice, the standing water could be disposed through drainage system and replaced with fresh water. This process could reduce the salinity of both soil and ground water (Ouda and Zohry 2016).

Finally, ECe along soil profile was highly significantly affected by different treatments according the following descending order: gypsum with subsoiling and compost $>$ gypsum with subsoiling and ammonia $>$ gypsum with subsoiling $>$ gypsum with compost $>$ with ammonia $=$ gypsum $>$ check treatment. It could be observed that the addition of ammonia with any treatments did not have appreciable effect on soil salinity in both growing seasons. Hence, combined application of gypsum requirement with compost and subsoiling played significant role in improving of soil salinity condition.

TABLE 4. Soil salinity $\left(\mathrm{dS} \mathrm{m}^{-1}\right)$ as affected by different treatments

\begin{tabular}{|c|c|c|c|c|c|c|c|c|}
\hline \multirow{3}{*}{ Treatments } & \multicolumn{4}{|c|}{ After first season } & \multicolumn{4}{|c|}{ After second season } \\
\hline & \multicolumn{4}{|c|}{ Soil depth (cm) } & \multicolumn{4}{|c|}{ Soil depth (cm) } \\
\hline & $0-20$ & $20-40$ & $40-60$ & Mean & $0-20$ & $20-40$ & $40-60$ & Mean \\
\hline Gypsum (G) & $7.74 \mathrm{c}$ & $9.58 b$ & $10.33 b$ & 9.22 & $5.12 b$ & $7.25 b$ & $8.15 b$ & 6.84 \\
\hline $\mathrm{G}+\mathrm{Ammonia}(\mathrm{A})$ & $7.74 \mathrm{c}$ & $9.65 b$ & $10.36 \mathrm{~b}$ & 9.25 & $5.02 \mathrm{~b}$ & $7.22 b$ & $8.13 b$ & 6.79 \\
\hline $\mathrm{G}+$ subsoiling $(\mathrm{S})$ & $6.12 \mathrm{~d}$ & $8.45 \mathrm{~d}$ & $9.36 \mathrm{~cd}$ & 7.98 & $3.13 \mathrm{~d}$ & $4.31 d$ & $6.81 \mathrm{~d}$ & 4.75 \\
\hline $\mathrm{G}+\mathrm{S}+\mathrm{A}$ & $6.01 \mathrm{e}$ & $8.36 \mathrm{~d}$ & $9.31 \mathrm{~d}$ & 7.89 & $3.11 \mathrm{~d}$ & $4.25 \mathrm{~d}$ & $6.80 \mathrm{~d}$ & 4.72 \\
\hline $\mathrm{G}+\mathrm{C}+\mathrm{S}$ & $5.71 \mathrm{f}$ & $8.01 \mathrm{e}$ & $8.94 \mathrm{~cd}$ & 7.55 & $2.95 \mathrm{e}$ & $4.10 \mathrm{e}$ & $5.35 \mathrm{e}$ & 4.13 \\
\hline $\mathrm{F}_{\text {test }}$ & $* *$ & $* *$ & $* *$ & & $* *$ & $* *$ & $* *$ & \\
\hline
\end{tabular}




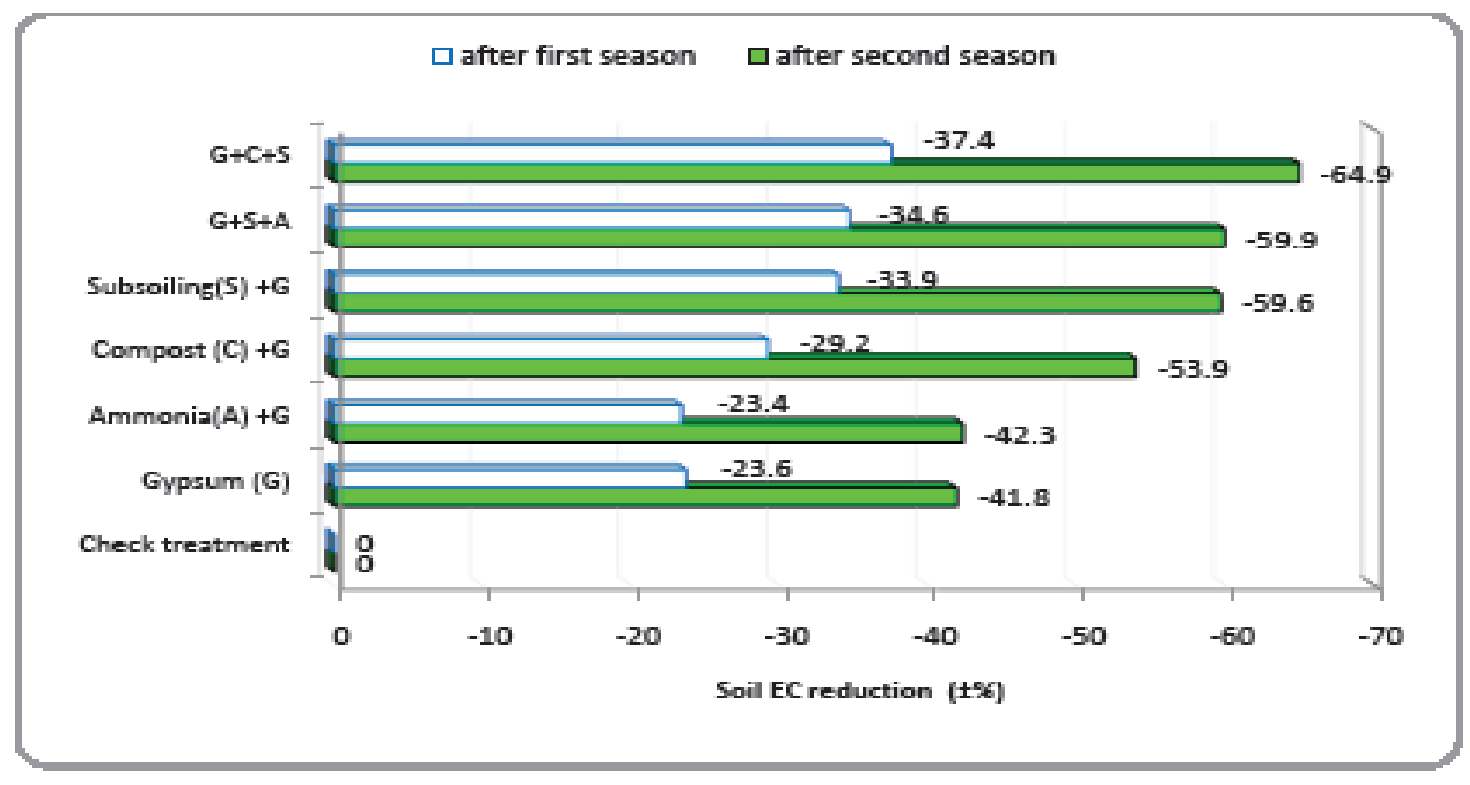

Fig. 2. Average soil EC reduction, $0-60 \mathrm{~cm}$ depth $( \pm \%)$ related to check treatment in first and second growing seasons

Sodium adsorption ratio (SAR)

Data in Table 5 showed that the sodium adsorption ratio (SAR) decreased by the application of gypsum from 17.5 before treatment to 14.27 and 12.77 after the $1^{\text {st }}$ and $2^{\text {nd }}$ seasons, respectively, with reduction of $8.23 \%$ and $15.5 \%$, respectively as compared with check treatment as shown in Fig.(2). These results may be due to the role of gypsum in providing $\mathrm{Ca}^{2+}$ cation to replace the exchangeable $\mathrm{Na}^{+}$on the exchange positions as observed by Sharma and Minhas (2005). Also, data revealed that the SAR was decreased to 14.27 and 12.79 due to application of gypsum combined with ammonia injection in the $1^{\text {st }}$ and $2^{\text {nd }}$ seasons, respectively, where the reductions were $8.2 \%$ and $15.4 \%$, respectively as compared with check treatment.So, application of ammonia injection had no effect on SAR.

Data in Table 5 and Fig. 3 showed that SAR was positively affected by an application of gypsum and compost, where it was decreased to 13.71 and 11.98 after the $1^{\text {st }}$ and $2^{\text {nd }}$ seasons, respectively, with reduction of $11.8 \%$ and $20.7 \%$, respectively as compared with check treatment. These results seem to agree with findings observed by Courtney and Harrington (2012) and El-Sanat et al.(2017). It could be observed that the application of gypsum combined with compost was more effective on SAR than gypsum only as observed also by Vance et al. (1998), Abdel-Fattah \& Merwad (2016) and
Ouda \& Zohry (2016). The reduction in soil SAR due to application of compost may be related to release of $\mathrm{Ca}^{2+}$ from soil $\mathrm{CaCo}_{3}$ or leaching of $\mathrm{Na}^{+}$ from soil (Sarwar et al., 2008). Or due to gum compounds, polysaccharides and organic acids produced from compost decomposition improved soil structure and help in leaching of soluble salts.

The application of subsoiling with gypsum or compost seems to be more effective in decreasing SAR. So, SAR was decreased due to application of subsoiling with gypsum after the 1st and 2nd seasons to 11.75 and 15.21 , respectively, where the corresponding reductions were $-24.4 \%$ and $32.4 \%$, respectively.

Also, the data refer to that SAR values were decreased due to application of subsoiling with gypsum and ammonia injection to 11.65 and 9.74 after the 1 st and 2 nd seasons, with reduction of $25.1 \%$ and $35.5 \%$, respectively compared to the check treatment. So, it could be observed that SAR was not clearly affected by ammonia injection applied with other amendments. On the other hand, SAR were more affected by the combined application of subsoiling with gypsum and compost where it was decreased to 11.26 and 9.57 in the 1st and 2nd seasons, respectively, with corresponding reduction of $27.6 \%$ and $36.7 \%$, respectively as compared with check treatment, (Table 5 and Fig. 3). 
TABLE 5. Sodium adsorption ratio (SAR) as affected by different treatments

\begin{tabular}{lcccccccc}
\hline & \multicolumn{3}{c}{ After first season } & \multicolumn{4}{c}{ After second season } \\
\cline { 2 - 9 } \multicolumn{1}{c}{ Treatments } & \multicolumn{3}{c}{ Soil depth $(\mathbf{c m})$} & \multicolumn{4}{c}{ Soil depth (cm) } \\
\cline { 2 - 9 } & $\mathbf{0 - 2 0}$ & $\mathbf{2 0 - 4 0}$ & $\mathbf{4 0 - 6 0}$ & Mean & $\mathbf{0 - 2 0}$ & $\mathbf{2 0 - 4 0}$ & $\mathbf{4 0 - 6 0}$ & Mean \\
\hline Check treatment & 13.23 & 15.63 & 17.79 & 15.55 & 12.91 & 15.1 & 17.31 & 15.11 \\
Gypsum (G) & 11.59 & 14.46 & 16.75 & 14.27 & 10.12 & 13 & 15.2 & 12.77 \\
G +Ammonia(A) & 11.59 & 14.46 & 16.75 & 14.27 & 10.13 & 13.1 & 15.15 & 12.79 \\
G +Compost (C) & 11.63 & 13.75 & 15.74 & 13.71 & 9.87 & 12.1 & 13.98 & 11.98 \\
G +Subsoiling (S) & 8.35 & 12.6 & 14.29 & 11.75 & 7.06 & 10.81 & 12.75 & 10.21 \\
G+ S + A & 8.27 & 12.48 & 14.2 & 11.65 & 6.45 & 10.19 & 12.59 & 9.74 \\
G+ S + C & 7.97 & 11.75 & 14.07 & 11.26 & 6.57 & 9.55 & 12.58 & 9.57 \\
\hline
\end{tabular}

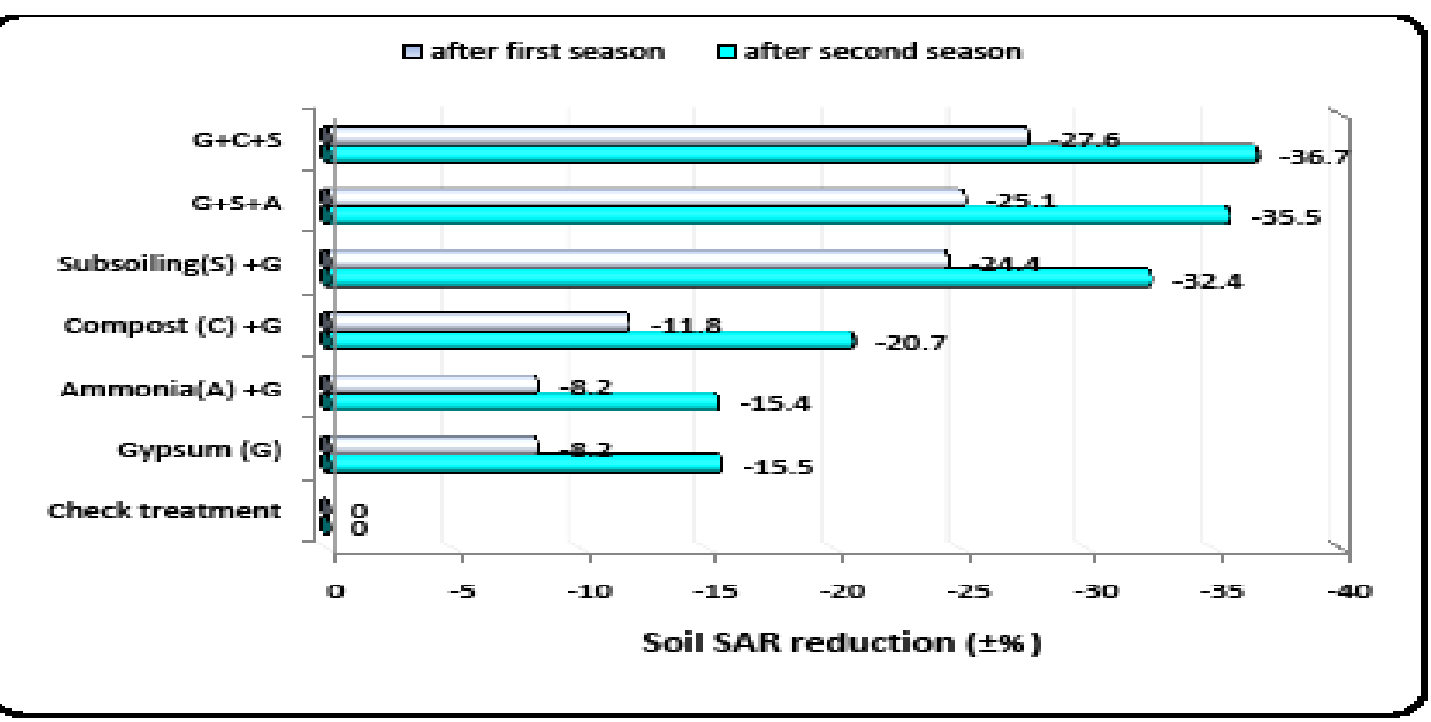

Fig. 3. Average soil SAR reduction $0-60 \mathrm{~cm}$ depth $( \pm \%)$ related to check treatment in first and second growing seasons

\section{$\mathrm{Ca} / \mathrm{Mg}$ ratio}

Figure 4 showed the effect of different treatments on $\mathrm{Ca} / \mathrm{Mg}$ ratio on soil surface. The obtained data indicated that $\mathrm{Ca} / \mathrm{Mg}$ ratio was increased by application of gypsum from 0.76 to 0.84 and 0.98 after the 1 st and 2 nd seasons, respectively. Gypsum application increased $\mathrm{Ca} 2+$ and modifies the ratio $\mathrm{Ca} 2+$ to $\mathrm{Mg} 2+$ on the exchange complex in soil. Also, $\mathrm{Ca} / \mathrm{Mg}$ ratio was slightly affected by ammonia injection when applied with gypsum, since it was increased to 0.85 and 0.98 after the 1 st and 2 nd seasons, respectively. The $\mathrm{Ca} / \mathrm{Mg}$ ratio was appreciably affected by application of gypsum combined with compost and it was increased to 1.08 and 1.16 after the $1^{\text {st }}$ and $2^{\text {nd }}$ seasons, respectively. These results may be due to organic materials improve the soil physicochemical properties that accelerate exchange of cations on soil solids and leaching of salts from the root zone (Clark et al., 2007)
Regarding the effect of subsoiling combined with gypsum on $\mathrm{Ca} / \mathrm{Mg}$ ratio. The data showed that it was increased to 0.97 and 1.03 after the $1 \mathrm{st}$ and 2 nd seasons, respectively. The values of $\mathrm{Ca} /$ $\mathrm{Mg}$ ratio were decreased up to (1.17 and 1.26) after harvesting of barely and rice due to application of gypsum, subsoiling and ammonia injection. On the other hand, $\mathrm{Ca} / \mathrm{Mg}$ ratio was increased due to application of gypsum with compost and subsoiling to 1.24 and 1.47 after the 1 st and 2 nd seasons, respectively. The removal of $\mathrm{Mg} 2+$ on soil complex and replaces by $\mathrm{Ca} 2+$ released from gypsum caused a positive increment of $\mathrm{Ca} /$ $\mathrm{Mg}$ ratio. This results seems nearly agreement with (Agar, 2012), who found that application of gypsum with sulfur are needed to remove the exchangeable $\mathrm{Mg} 2+$ from soil profiles and both materials together are more effective than one of them individually. 


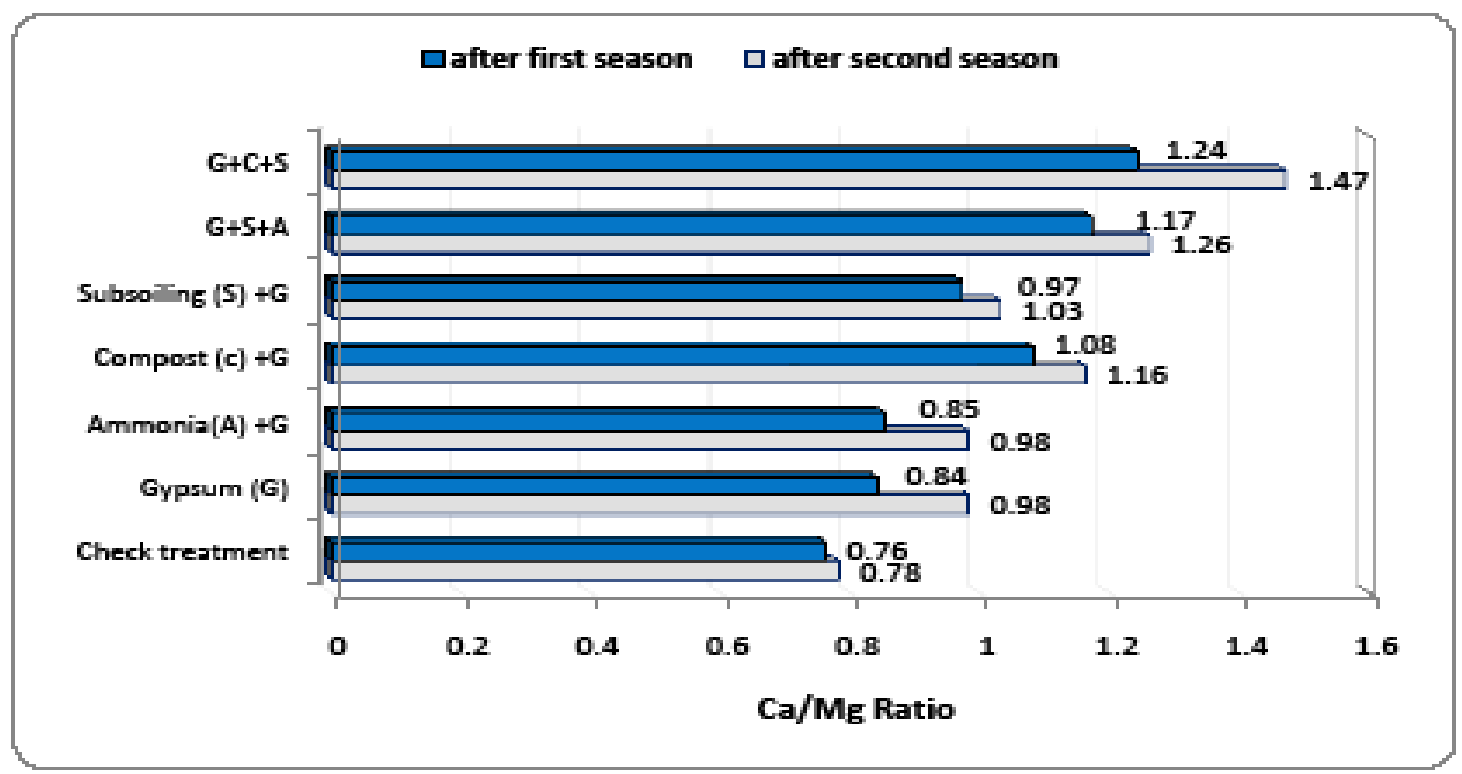

Fig. 4. Average of $\mathrm{Ca} / \mathrm{Mg}$ ratio of soil layer $(0-60 \mathrm{~cm}$ depth) as affected by different treatments

\section{Soil physical properties}

Soil bulk density (BD)

Results in Table 6 revealed that treatments application seemed to be effective in producing relatively low values of soil bulk density especially in the surface layers. Soil bulk density ranged from 1.42 to $1.44 \mathrm{Mgm}-3$ before experimental installation while, after two seasons from experimental installation bulk density were reduced and varied from 1.26 to $1.42 \mathrm{Mgm}-3$

Table 6 and Fig 5 showed that soil BD decreased by the application of gypsum $(1.42$ and $1.40 \mathrm{Mg} \mathrm{m}-3$ ) in both seasons, with reduction of $1.4 \%$ and $2.6 \%$, as compared with the check treatment. Also, data referred that soil BD decreased by application of gypsum combined with ammonia injection ( 1.39 and $1.41 \mathrm{Mgm}-3$ ) in both seasons, with reduction of 2.1 and $3.2 \%$, as compared with the check treatment.

Table 6 and Fig 5 referred that the BD decreased to 1.37 and $1.34 \mathrm{Mg} \mathrm{m}-3$ by gypsum and subsoiling treatments in both seasons, with the reduction of $4.9 \%$ and $6.7 \%$ as compared with check treatment. These results referred to the role ameliorative effect of the subsoiling on improvement of soil drainage, soil aeration and water infiltration (El-Henawy et al., 2016).

The data showed also that the BD was decreased due to application of gypsum combined with compost and mole drains from $1.49 \mathrm{Mg} \mathrm{m}^{-3}$ of the check treatment to $1.38 \mathrm{Mg} \mathrm{m}^{-3}$ and 1.31 $\mathrm{Mg} \mathrm{m}^{-3}$ after the $1^{\text {st }}$ and $2^{\text {nd }}$ seasons, respectively, whereas the reductions were $7.4 \%$ and $12.1 \%$ respectively. So, the effect of different treatments on soil bulk density followed the ascending order Egypt. J. Soil Sci., 58, No.2 (2018) such as: $\mathrm{G}+\mathrm{C}+\mathrm{M}>\mathrm{G}+\mathrm{C}=\mathrm{G}+\mathrm{M}+\mathrm{A}>\mathrm{G}+\mathrm{M}>$ $\mathrm{G}+\mathrm{A}=\mathrm{G}>$ check treatment.

This means that gypsum +compost + mole drains effects were superior to others treatments on reducing soil bulk density. It could be attributed to the effects of mole on breaking soil clods and bigger granular into smaller crumbs as well as breaking and cracking the compacted layers (Antar et al., 2008). It could be observed that there were remarkable changes on BD by application of compost and/or subsoiling with any treatments in both growing seasons.

\section{Soil porosity}

Data in Table 6 showed that the application of gypsum increased the soil porosity from $45.66 \%$ and $45.79 \%$ of the check treatment to $46.42 \%$ and 46.79 in growing seasons. Also, the application of gypsum combined with the compost had positive effect on the soil porosity since was increased to $48.68 \%$ and $49.69 \%$ after harvesting of barely and rice, respectively .Thus, the role of compost may be related to increase of soil granulation, increase porosity and decrease soil density and improving soil properties, (El-Henawy et al., 2016).

The data referred also that application of gypsum with subsoiling had positive effect on increasing of the soil porosity after the first and second seasons (48.30 and 49.43, respectively). The highest values of soil porosity after the first and second seasons (49.81\% and 52.33\%, respectively) were recorded by the application of gypsum with both compost and subsoiling as compared with the check treatment. So, it can be concluded that gypsum combined with compost and the subsoiling is the most effective treatment 
TABLE 6. Soil bulk density $\left(\mathrm{Mg} \mathrm{m}^{-3}\right)$ and total porosity (\%) as affected by different treatments

\begin{tabular}{|c|c|c|c|c|c|}
\hline \multirow{2}{*}{ Treatments } & \multirow{2}{*}{$\begin{array}{l}\text { Soil depth } \\
\text { (cm) }\end{array}$} & \multicolumn{2}{|c|}{${\text { After } 1^{\text {st }} \text { season }}$} & \multicolumn{2}{|c|}{$\begin{array}{c}\text { After } 2^{\text {nd }} \text { season } \\
\end{array}$} \\
\hline & & $\mathrm{BD}\left(\mathrm{Mg} \mathrm{m}^{-3}\right)$ & Porosity \% & $\mathrm{BD}\left(\mathrm{Mg} \mathrm{m}^{-3}\right)$ & Porosity \% \\
\hline \multirow{3}{*}{ Check treatment } & $0-20$ & 1.43 & 46.04 & 1.43 & 46.04 \\
\hline & $20-40$ & 1.44 & 45.66 & 1.44 & 45.66 \\
\hline & $40-60$ & 1.45 & 45.28 & 1.44 & 45.66 \\
\hline \multirow[t]{2}{*}{ Average } & & 1.44 & 45.66 & 1.44 & 45.79 \\
\hline & $0-20$ & 1.40 & 47.17 & 1.37 & 48.30 \\
\hline \multirow[t]{2}{*}{ Gypsum (G) } & $20-40$ & 1.42 & 46.42 & 1.41 & 46.79 \\
\hline & $40-60$ & 1.44 & 45.66 & 1.42 & 46.42 \\
\hline \multirow[t]{2}{*}{ Average } & & 1.42 & 46.42 & 1.40 & 47.17 \\
\hline & $0-20$ & 1.38 & 47.92 & 1.36 & 48.68 \\
\hline \multirow[t]{2}{*}{$\mathrm{G}+$ Ammonia (A) } & $20-40$ & 1.42 & 46.42 & 1.40 & 47.17 \\
\hline & $40-60$ & 1.44 & 45.66 & 1.42 & 46.42 \\
\hline \multirow[t]{2}{*}{ Average } & & 1.41 & 46.67 & 1.39 & 47.42 \\
\hline & $0-20$ & 1.35 & 49.06 & 1.31 & 50.57 \\
\hline \multirow[t]{2}{*}{$\mathrm{G}+$ Compost $(\mathrm{C})$} & $20-40$ & 1.36 & 48.68 & 1.34 & 49.43 \\
\hline & $40-60$ & 1.37 & 48.30 & 1.35 & 49.06 \\
\hline \multirow[t]{2}{*}{ Average } & & 1.36 & 48.68 & 1.33 & 49.69 \\
\hline & $0-20$ & 1.36 & 48.68 & 1.33 & 49.81 \\
\hline \multirow[t]{2}{*}{$\mathrm{G}+$ subsoiling $(\mathrm{S})$} & $20-40$ & 1.37 & 48.30 & 1.34 & 49.43 \\
\hline & $40-60$ & 1.38 & 47.92 & 1.36 & 48.68 \\
\hline \multirow[t]{2}{*}{ Average } & & 1.37 & 48.30 & 1.34 & 49.43 \\
\hline & $0-20$ & 1.34 & 49.43 & 1.31 & 50.57 \\
\hline \multirow[t]{2}{*}{$\mathrm{G}+\mathrm{S}+\mathrm{A}$} & $20-40$ & 1.36 & 48.68 & 1.33 & 49.81 \\
\hline & $40-60$ & 1.38 & 47.92 & 1.35 & 49.06 \\
\hline \multirow[t]{2}{*}{ Average } & & 1.36 & 48.68 & 1.33 & 49.81 \\
\hline & $0-20$ & 1.31 & 50.57 & 1.25 & 52.83 \\
\hline \multirow[t]{2}{*}{$\mathrm{G}+\mathrm{C}+\mathrm{S}$} & $20-40$ & 1.33 & 49.81 & 1.26 & 52.45 \\
\hline & $40-60$ & 1.35 & 49.06 & 1.28 & 51.70 \\
\hline Average & & 1.33 & 49.81 & 1.26 & 52.33 \\
\hline
\end{tabular}

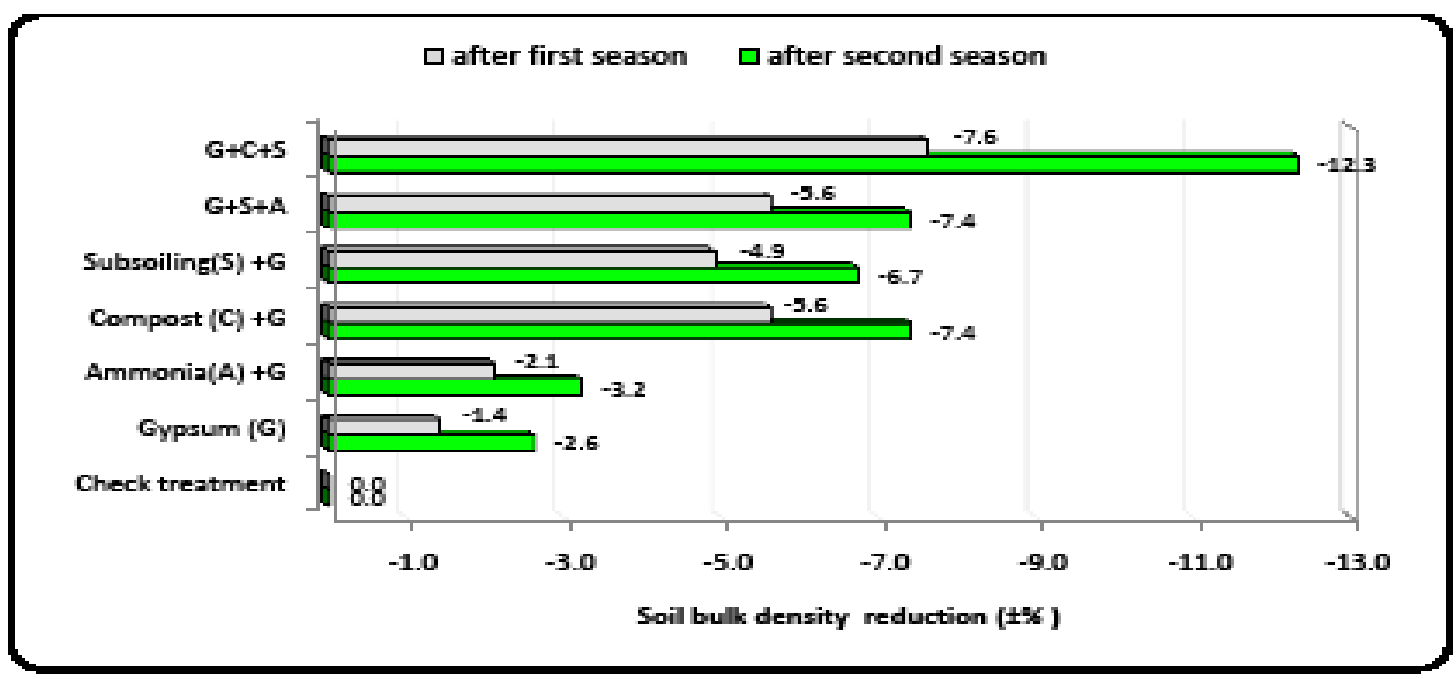

Fig. 5. Average of soil bulk density reduction 0-60 $\mathrm{cm}$ depth $( \pm \%)$ related to check treatment in first and second growing seasons 
that ameliorate saline sodic clay soil.

The effect of different treatments on soil porosity can be arranged in the following ascending order: $\mathrm{G}+\mathrm{C}+\mathrm{S}>\mathrm{G}+\mathrm{S}+\mathrm{A}>\mathrm{G}+\mathrm{C}>$ $\mathrm{G}+\mathrm{S}>\mathrm{G}+\mathrm{A}>\mathrm{G}>$ Check treatment.

Soil basic infiltration rate (IR)

Infiltration rate (IR) is the volume flux of water flowing into the profile per unit of soil surface area. Table 7 showed that the application of gypsum and/or without ammonia injection slightly increased IR from $0.32 \mathrm{~cm} / \mathrm{h}$ of check treatment to about $0.33 \mathrm{~cm} / \mathrm{h}$ after harvesting of barely and rice, where the increase was about $3.1 \%$. Also, the data referred that the IR was increased to $\left(0.51\right.$ and $\left.0.56 \mathrm{~cm} \mathrm{~h}^{-1}\right)$ after first and second seasons, due to application of gypsum with compost, whereas the relative increase were $59.4 \%$ and $75 \%$, respectively as compared with check treatment. In addition, gypsum combined with subsoiling increased IR in the $1^{\text {st }}$ and $2^{\text {nd }}$ seasons (about 0.45 and $0.48 \mathrm{~cm} \mathrm{~h}^{-1}$, respectively. with the increase of about $40.6 \%$ and $50.0 \%$, respectively comparing to the check treatment. This may be due to the improved drainage under subsoiling treatments that gave the top soil layer a chance to dry and permitted for shrinkage and formation of water passage ways which allowed a rather easier movement of water through mole into net drainage (El-Henawy et al., 2016).

Addition of gypsum, subsoiling and ammonia injection increased IR in the 1 st and 2 nd seasons (about 0.46 and $0.49 \mathrm{cmh}-1$, respectively. with the increase of about $43.8 \%$ and $53.1 \%$, respectively comparing to the check treatment. On the other hand, the obtained data showed that the IR was clearly increased due to application of gypsum with compost and subsoiling (1.16 and $\left.1.21 \mathrm{cmh}^{-1}\right)$ after first and second seasons, respectively, whereas the relative increased were about $262.5 \%$ and $278.1 \%$, respectively compared with check treatments. Hence subsoiling can be used to improve the efficiency of drainage and an adequate auxiliary drainage treatments in clay soils of low level with a saline water table to reserve the root zone from water logging and salinity. This results may be due to increasing of root resudies through soil profile by application of organic manure and gypsum with subsoiling.

The effect of different soil amendments on soil basic IR can be arranged in the following ascending order: $\mathrm{G}+\mathrm{C}+\mathrm{S}>\mathrm{G}+\mathrm{C}>\mathrm{G}+\mathrm{S}+\mathrm{A} \approx$ $\mathrm{G}+\mathrm{S}>\mathrm{G}+\mathrm{A}=\mathrm{G}>$ check treatment.

It can be observed from the results that the IR values were not clearly affected by the combination of ammonia injection with other soil amendments. The positive effect on IR may be due to that application of gypsum increases of soluble $\mathrm{Ca}^{2+}$ to overcome the dispersion effects of $\mathrm{Na}^{+}$ions and promote flocculation and structure development in dispersed soils. The permeability of clay soils is strongly dependent on the type of exchangeable cations and it decreases with increasing of the soil sodicity, (Shainberg et al., 1988). Also, the positive effect of compost on decreasing of the bulk density and increasing the soil porosity and IR values, consequently ease leaching the salts from upper soil layer and

TABLE 7 . Soil basic infiltration rate (IR, $\left.\mathrm{cm} \mathrm{h}^{-1}\right)$ as affected by different treatments

\begin{tabular}{|c|c|c|c|c|}
\hline treatments & $1^{\text {st }}$ season & $\begin{array}{c}\text { Relative variation } \\
( \pm \%)\end{array}$ & $2^{\text {nd }}$ season & $\begin{array}{c}\text { Relative variation } \\
( \pm \%)\end{array}$ \\
\hline Check treatment & 0.32 & 0 & 0.32 & 0 \\
\hline Gypsum (G) & 0.33 & 3.1 & 0.33 & 3.1 \\
\hline $\mathrm{G}+$ Ammonia $(\mathrm{A})$ & 0.33 & 3.1 & 0.34 & 6.3 \\
\hline $\mathrm{G}+$ Compost $(\mathrm{C})$ & 0.51 & 59.4 & 0.56 & 75 \\
\hline $\mathrm{G}+$ Subsoiling $(\mathrm{S})$ & 0.45 & 40.6 & 0.48 & 50 \\
\hline $\mathrm{G}+\mathrm{S}+\mathrm{A}$ & 0.46 & 43.8 & 0.49 & 53.1 \\
\hline $\mathrm{G}+\mathrm{C}+\mathrm{S}$ & 1.16 & 262.5 & 1.21 & 278.1 \\
\hline
\end{tabular}

movement far by subsoiling, similar results were nearly obtained by Saied et al. (2017). This may be also due to improving drainage system in the area by subsoiling, in addition to improve soil physical properties as a result of decreasing $\mathrm{Mg}$ / Ca ratio in soil is less the unity which causes a increment in infiltration rate.

Yield of barley and rice

Table 8 showed that grain and straw yields of

Egypt. J. Soil Sci., 58, No.2 (2018) barely and rice were highly significantly increased by application of gypsum. These results may be due to application of $\mathrm{Ca}$ amendments as soil modifiers that can prevent development of sodicity which is directly related to plant growth, crop productivity and crop yields (Wong et al., 2009). And soluble $\mathrm{Ca}^{2+}$ released by gypsum could be a factor that alleviated the stress effect of $\mathrm{Na}^{+}$on rice growth (Chi et al., 2012). Also, the application of gypsum combined with compost, ammonia injection or 
subsoiling highly significantly increased the grain and straw yield of barely and rice, and all of them were superior to gypsum individually or the check treatment. Beneficial effects of compost applications to crops are many and varied. Most of them are due to soil quality improvement and nutrient enhancement which resulted in increases in yield of barley and rice.

Data showed that grain and straw yields of barely and rice were highly significantly increased and recorded the highest values due to application of gypsum combined with subsoiling and compost or ammonia injection. As a general, the application of gypsum with subsoiling and ammonia injection considered as an effective management strategy for amelioration of salt affected soils and achieved the highest productivity. Finally, the soil productivity as affected by different soil amendments can be arranged in the following descending order: $\mathrm{G}+\mathrm{S}+\mathrm{A}>\mathrm{G}+\mathrm{S}+\mathrm{C}>\mathrm{G}+\mathrm{S}$ $>\mathrm{G}+\mathrm{C}>\mathrm{G}+\mathrm{A}>\mathrm{G}>$ check treatment.

The beneficial effect of the ameliorative role of the previous treatments in salt affected soils may be attributed to that gypsum and compost

TABLE 8. Yield of barley and rice $\left(\mathrm{Mgfed}^{-1}\right)$ as affected by different treatments

\begin{tabular}{|c|c|c|c|c|}
\hline \multirow{2}{*}{ Treatments } & \multicolumn{2}{|c|}{ Barley (Mg fed $\left.{ }^{-1}\right)$} & \multicolumn{2}{|c|}{ Rice (Mg fed $\left.{ }^{-1}\right)$} \\
\hline & Grain & Straw & Grain & Straw \\
\hline Check treatment & $0.788 \mathrm{f}$ & $1.020 \mathrm{f}$ & $0.750 \mathrm{i}$ & $1.010 \mathrm{i}$ \\
\hline Gypsum (G) & $1.620 \mathrm{e}$ & $1.855 \mathrm{e}$ & $1.50 \mathrm{f}$ & $1.80 \mathrm{f}$ \\
\hline $\mathrm{G}+\mathrm{Ammonia}(\mathrm{A})$ & $1.650 \mathrm{~d}$ & $1.890 \mathrm{e}$ & $1.82 \mathrm{e}$ & $2.15 \mathrm{e}$ \\
\hline $\mathrm{G}+$ Compost $(\mathrm{C})$ & $1.655 \mathrm{~d}$ & $1.955 \mathrm{~d}$ & $1.93 \mathrm{~d}$ & $2.20 \mathrm{~d}$ \\
\hline $\mathrm{G}+$ Subsoiling $(\mathrm{S})$ & $1.786 \mathrm{c}$ & $1.987 \mathrm{c}$ & $1.17 \mathrm{c}$ & $2.37 \mathrm{c}$ \\
\hline $\mathrm{G}+\mathrm{S}+\mathrm{A}$ & $1.991 \mathrm{a}$ & $2.250 \mathrm{a}$ & $2.36 \mathrm{a}$ & $2.76 \mathrm{a}$ \\
\hline $\mathrm{G}+\mathrm{S}+\mathrm{C}$ & $1.859 b$ & $2.080 \mathrm{~b}$ & $2.32 b$ & $2.54 b$ \\
\hline Ftest & $* *$ & $* *$ & $* *$ & $* *$ \\
\hline LSD0.05 & 0.012 & 0.011 & 0.009 & 0.014 \\
\hline LSD0.01 & 0.009 & 0.008 & 0.007 & 0.011 \\
\hline
\end{tabular}

on improvement soil properties such soil salinity and basic infiltration rate. The obtained results are supported by the data obtained by Saied et al. (2017) and El Sanat et al. (2017). The relation between soil salinity and yield were supported by Amer et al. (2017) who found that the yield potential in the parts at Kafr El-Sheikh Governorate with relative low EC soils (4.6-4.9 $\mathrm{dSm}^{-1}$ ) was about $10 \%$ higher than that in parts with relatively high salinity $\left(6.8 \mathrm{dSm}^{-1}\right)$.

\section{Economical evaluation}

Data in Table 9 showed that costs of agriculture treatment materials and price yield of barely and rice according the local market. Data in Fig. 6 and 7 showed that the gross and net incomes were obviously increased by gypsum combined with subsoiling and ammonia injection or compost. The experimental plot achieved gypsum + subsoiling + ammonia together achieved the highest values of gross and net incomes of barley (5730.2 and

TABLE 9. Costs of agriculture treatment materials and price yield of barely and rice

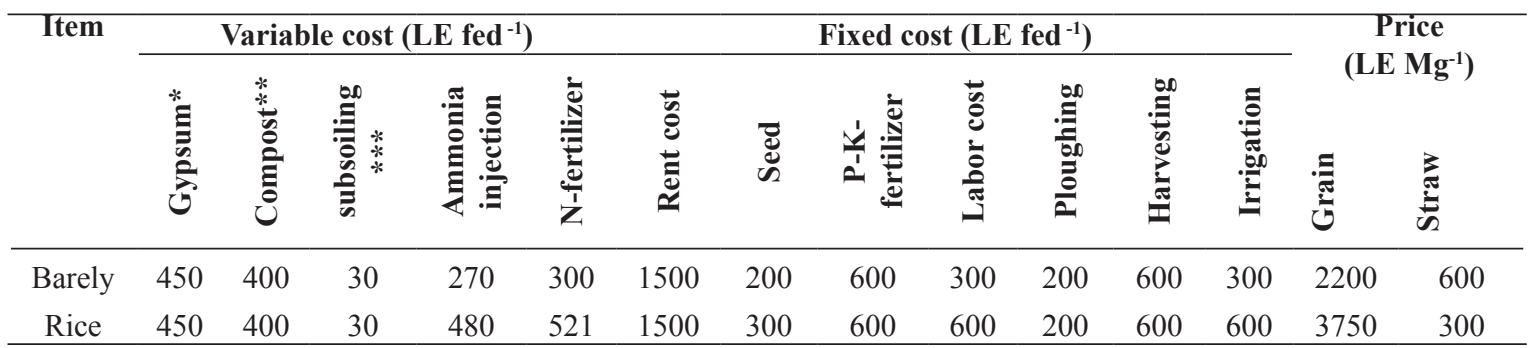

Notes:

1- Total cost(LE Fed. -1$)=$ fixed cost(LE Fed. -1$)+$ variable cost (LE Fed. -1$)$

2- Gross income (LE Fed. -1$)=$ grain yield $x$ price + straw yield $x$ price

3- Net income $=$ gross income $($ LE Fed-1) - total costs (LE fed-1)

4- Economic efficiency (Eco. Eff.) = Gross income (LE Fed-1) /total cost (LE Fed-1)

*Total cost for gypsum (900LEFed.-1) for barely and rice

** Total cost for compost (800LEFed.-1) for barely and rice

*** Total cost for subsoiling (120LEFed.-1) for four seasons 


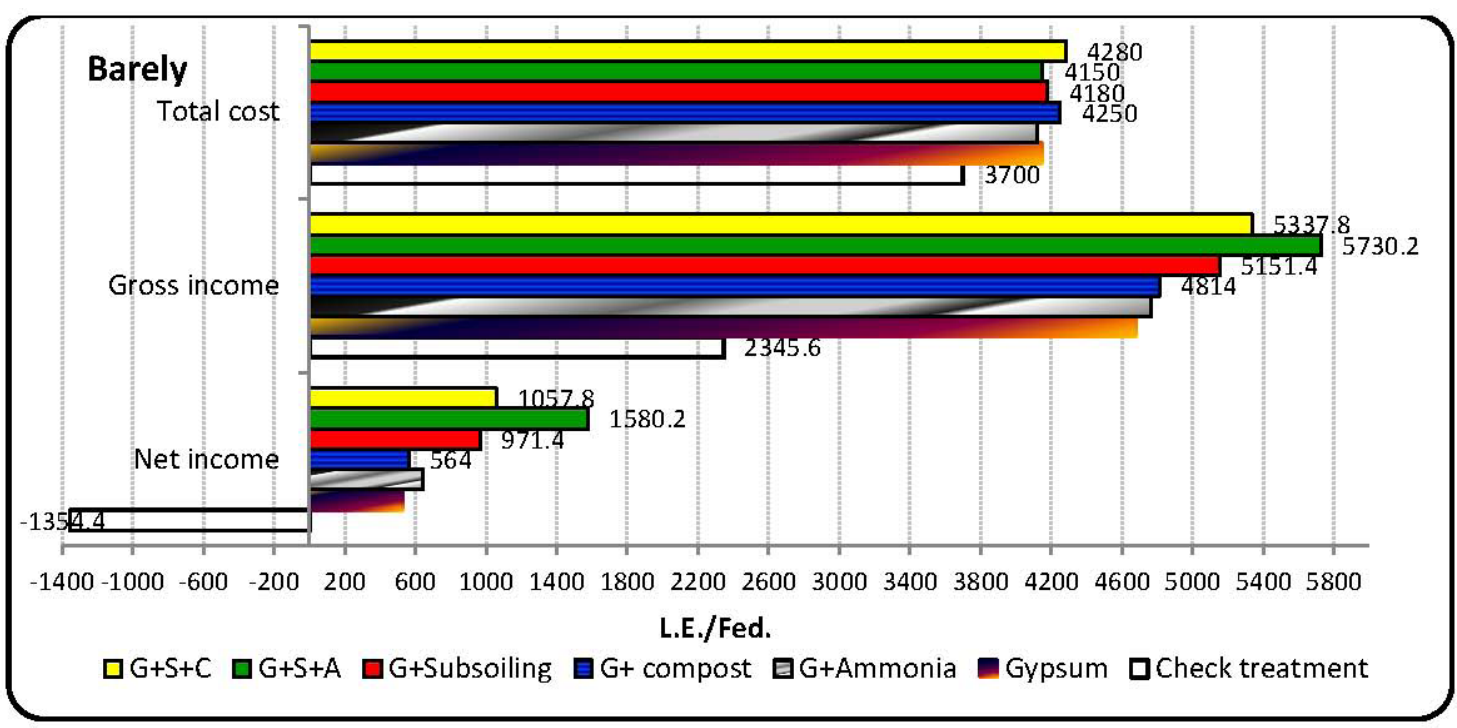

Fig. 6. Total cost, gross income and net income $\left(\mathrm{LE}\right.$ fed $\left.^{-1}\right)$ from yield of barely as affected by different treatments

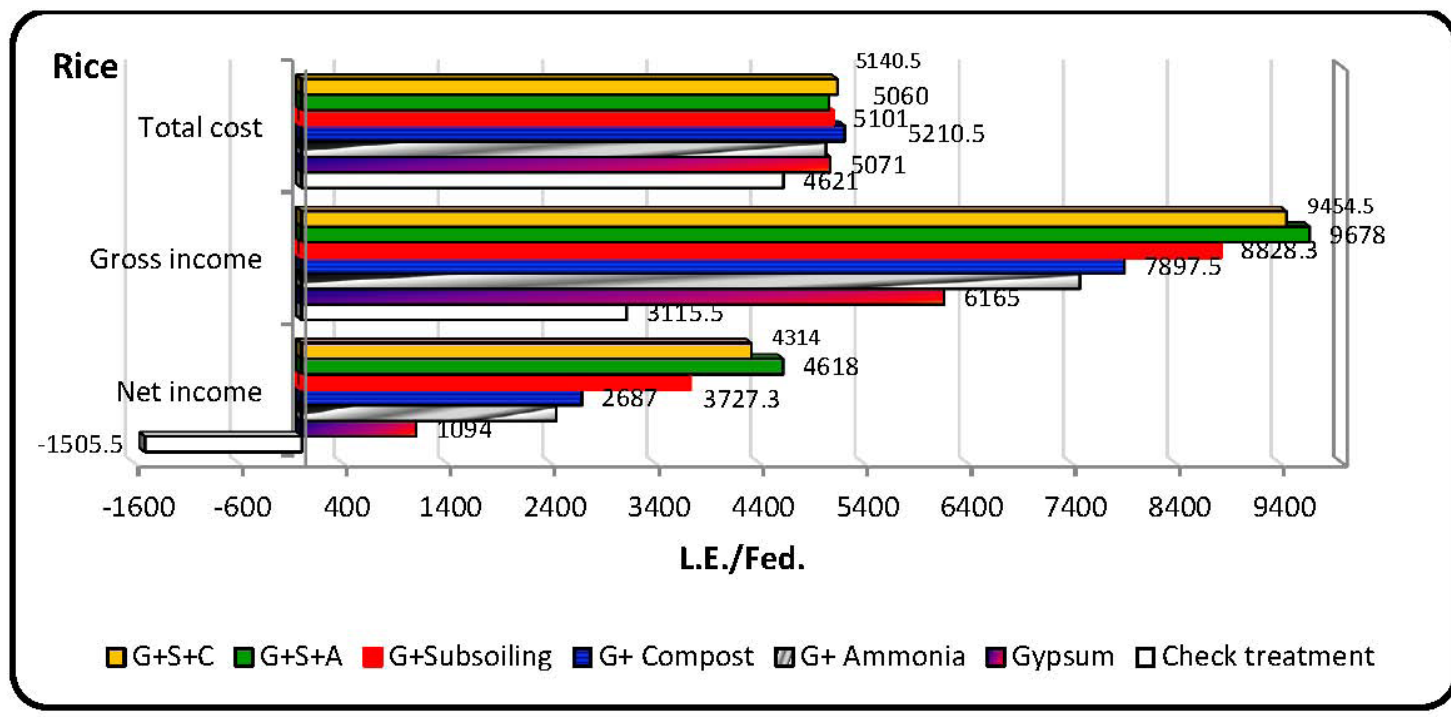

Fig.7. Total cost, gross income and net income $\left(\mathrm{LE} \mathrm{fed}^{-1}\right)$ for yield of rice as affected by different treatments

1550.2 LEFed.-1, respectively) and rice (9678 LEfed.-1and 5298 LEFed.-1, respectively). Concerning the economic efficiency, the highest values 1.38 and 1.91) for barley and rice were recorded due to the combined between gypsum, subsoiling and ammonia injection. Theses results are consistent with those obtained by Osman et al. (2013) who concluded that anhydrous ammonia increased gross income, net income, benefit / costs ratio and profitability of rice.

\section{Conclusion}

It could be concluded that the application of gypsum requirements to the soil combined with ammonia gas and subsoiling could be economically used to improve the yield of cereal crops such as barley and rice. Some physiochemical properties of salt affected soil were improved by application of gypsum, compost and subsoiling at Kafr El-Sheikh Governorate. 


\section{References}

Abdel-Fattah, M. K. (2012) Role of gypsum and compost in reclaiming saline-sodic soils. J. Agric. and Vet. Sci., 1 (3), 30-38. www.iosrjournals.org

Abdel-Fattah, M. K. and Merwad, A. M. A. (2016) Approach for reclamation and improving fertility of saline-sodic soils, Egypt. J. Soil Sci. 56 (4), 573588.

Agar, A. I. (2012) Improvement of exchangeable Ca/ $\mathrm{Mg}$ ratio by using gypsum and waste of sulfur in magnesium-affected soils. Afr. J. Agric. Res., 7 (14), 2205-2214.Available online at http://www. academic journals.org/AJAR.

Aiad, M. A. (2014) Effect of mole drains and compost application on some soil properties, water relations and its productivity at North Delta. J. Soil Sci. and Agric. Eng., Mansoura Univ., 5 (2), 219 -236.

Amer, M..M., Aboelsoud, H.M., Omer, El.S.H. and Zoghdan, M.G. (2017) Assessment the impact of shallow groundwater on soil salinity and biomass yield using remote sensing and GIS techniques in North Nile Delta. EJSS. 58,1. 2018, DOI: 10.21608/ EJSS.2017.1909.1135.

Ansari M.A., Kumar S.A., Subbarayappa C.T. and Sudhir, K. (2010) Effect of calcium-magnesium ratios in an alfisol on growth and yield of finger millet in a red sandy clay loam soil. Mysore J. Agric. Sci., 44 (4),735-741.DOI:10.1104/pp.103.033027.

Antar, S. A., El-Henawy, A. S. and Atwa, A. A. E. (2008) Improving some properties of heavy clay salt affected soil as a result of different subsurface tillage. J. Agric. Sci. Mansoura Univ., 33 (10), 7675- 7687.

Bardhan, G., Chaudhar, I S.K. and Mohapatra P.K. (2007) Effect of irrigation water quality on saturated hydraulic conductivity of typic haplustert, vertic haplustept, and lithic ustorthent, Soil J. Agric. Phys., 7, 38-46.DOI:10.1111.

Campbell, D.J. (1994) Determination and use of bulk density in relation to soil compaction. In Soane and Ouwerk (Ed.). Soil Compaction in Crop Production. Elsevere, London, Amsterdam.

Chi, C. M., Zhao, C. W., Sun, X. J. and Wang, Z. C. (2012) Reclamation of saline-sodic soil properties and improvement of rice (Oriza sativa L.) growth and yield using desulfurized gypsum in the west of Songnen Plain, northeast China. Geoderma, $187 \&$ 188, 24-30. http://dx.doi.org/10.1016/j. geoderma.2012.04.005.

Clark, G., Dodgshun, N., Sale, P. and Tang, C. (2007) Changes in chemical and biological properties of a sodic clay subsoil with addition of organic amendments. Soil Biology and Biochemistry, 39, 2806-2817.

Courtney, R. and Harrington, T. (2012) Growth and nutrition of Holcuslanatus in bauxite residue amended with combinations of spent mushroom compost and gypsum. Land Degrad. Dev. 23, 144-149. (wiley online library.com) DOI: $10.1002 /$ ldr.1062.

Dontsova, K. and Norton, L.D. (2001) Effects of exchangeable $\mathrm{Ca} / \mathrm{Mg}$ ratio on soil clay flocculation, infiltration and erosion. In: D.E. Stott, R.H. Mohtar and G.C. Steinhardt (Ed.). Selected papers from the $10^{\text {th }}$ International Soil Conservation Organization Meeting, May 24-29, 1999 at Purdue Univ. and the USDA-ARS National Soil Erosion Res. Laboratory, P.580-585.

El-Henawy, A. S., Atta, M. H. and Antar, A. S. (2016) Impact of mole drains and $\mathrm{N}$-fertilizer rates on some soil properties and sugar beet production in clay Soil. Inter. J. Ad. Res., 4 (6), 220-229, http:// www.journalijar.com, DOI:10.21474/IJAR01.

El-Sanat, G.M.A., Aiad, M.A. and Amer, M.M. (2017) Impact of some soil amendments and different tillage depths on saline heavy clay soils properties and its yield water productivity. IJPSS, 14 (2), 1-13, http://www.sciencedomain.org.

FAO (2005) Integrated management for sustainable use of salt-affected soils. (Eds.: A. Mashali, D.L. Suarez, H. Nabhan, R. Rabindra) Soils Bulletin, Rome.

FAO and IIASA (2000) Diagnosis and improvement of saline and alkali sols, USDA Handbook No 60, U.S. Salinity Lab. Staff (1954), Washington.

Fisher, M. (2011) Amending soils with gypsum. Crops \& Soils magazine, Nov.-Dec. 2011, American Soc. of Agron., mfisher@sciencesocieties. org.

Garcia, I. (1978) Soil water engineering laboratory manual. Department of agric. and chemical engineering. Colorado State Univ., Fortacollin Colorado, USA.

Genever, L. (2010) Improving soils for better returns .Beef and sheep BRP Manual. Agric. and Horticulture Development Board.

Ghafoor, A., Murtaza, G., Ahmad, B. and Boers, T.M. (2008) Evaluation of amelioration treatments and economic aspects of using saline-sodic water for rice and wheat production on salt affected soils under arid land conditions. Irrigation and Drainage, 57, 424-434.

Ghulam, S., Muhammad, I., Mukkram, A. T., Yasir I., Muhammad, S. H., Noor-us-Sabah, Kyung-Hwa, H., Sang-Keun, H. and Yong-Seon, Z. (2011) Effect 
of compost and gypsum application on the chemical properties and fertility status of saline-sodic soil. Korean J. Soil Sci. Fert. 44 (3), 510-516.

Gomez, K.A. and, Gomez, A.A. (1984) Statistical Procedures for Agric. Res., $2^{\text {nd }}$ edition. John Wiley and Sons, New York, 680.

Haghnazari, F., Shahgholi, H. and Feizi, M. (2015) Factors affecting the infiltration of agricultural soils: review. Inter. J. of Agronomy and Agric. Res. (IJAAR), ISSN: 2223-7054 (Print) 2225-3610 (Online), 6 (5), 21-35.

Hannan, J.M. (2011) Potassium-magnesium antagonism in high magnesium vine yard soils. Master Thesis of Sciences, Iowa State University. Paper12096, http://lib.dr.iastate.edu/etd.

Horneck, D.A., Ellsworth, J.W. , Hopkins, B.G., Sullivan, D.M. and Stevens, R.G. (2007) Managing of salt-affected soils for crop production. PNW601-E.

Moradi, F. and Ismail, A.M. (2007) Responses of photosynthesis, chlorophyll fluorescence and ROSScavenging systems to salt stress during seedling and reproductive stages in rice. Ann Bot. 99, 1161-1173.

Moukhtar, M.M., El-Arquan, M.Y.S., El-Hadidy, E.M. and El-Shewikh, M.A.B. (2003) Amelioration of salt affected soils in north Dakhlia Governorate through application of tile drainage and subsoiling. J.Agric. Sci. Mansoura Univ., Special Issue, Sci. Symp. On problems of soils and waters in Dakhlia and Damietta Governorate. March 18.

Negm, A.M. (2016) The Nile Delta, Hdb Env. Chem., DOI 10.1007/698_2016_102, (C) Springer International Publishing AG .

Osman E. A. M., EL- Masry, A. A. and Khatab, K. A. (2013) Effect of nitrogen fertilizer sources and foliar spray of humic and/or fulvic acids on yield and quality of rice plants. Adv. Appl. Sci. Res., 4 (4), 174-183

Ouda, S. A.H. and Zohry, A. (2016) Management of Climate Induced Drought and Water Scarcity in Egypt, chapter 6, (77-97). Springer Briefs in Environmental Science, DOI 10.1007/978-3-31933660-2_6.

Page A.L.R., Miller, H. and Keeney, D.R. (1982) Methods of soil analysis. Part 2: Chemical and Microbiological Properties. $2^{\text {nd }}$ edition. Agronomy Monograph, No. 9, ASA, CSSA,CSSA and SSSA, Madiso.

Qadir, M., Tubeileh, A., Akhtar, J., Larbi, A., Minhas, P. S. and Khan, M. A. (2008) Productivity enhancement of salt-affected environments through crop diversification. Land Deg. Devel., 19, 429-

\section{3. http://dx.DOI:10.1002/ldr.853}

Rhoades, J.D., Kandiah, A. and Mashali A.M. (1992) The use of saline waters for crop production. FAO, Irrigation and Drainage Paper Food and Agric. Organization of The united Nations Rome.

Saied, M. M., Elsanat, G. M., Talha, N. I. and El Barbary, S. M. (2017) On- Farm Soil Management Practices for Improving Soil Properties and Productivity of Rice and Wheat under Salt-Affected Soils at North Delta. Egypt J.Soil Sci. 57 (4) , 445 - 453.

Sarwar, G., Schmeisky,H., Hussain, N., Muhammad, S., Ibrahim, M. and Safdar, E. (2008) Improvement of soil physical and chemical properties with compost application in rice-wheat cropping system. Pak. J. Bot. 40, 275-282.

Shainberg, I., Alperovitch, N. and Keren, R. (1988) Effect of management on the hydraulic conductivity of Na-semectite-sand mixtures. Clays and Clay Minerals, 36 (5), 432-438.

Sharma, B. R. and Minhas, P. S. (2005) Strategies for managing saline/alkali waters for sustainable agric. production in South Asia. Agric. Water Manag., 78, 136-151. http://dx.doi.org/10.1016/j.agwat. 2005.04.019.

Tejada, M., Garcia, C., Gonzalez, J.L. and Hernandez, M.T. (2006) Use of organic amendments as a strategy for saline soil remediation: Influence on the physical, chemical, and biological properties of soil. Soil Biology and Biochemistry, 38, 1413-1421.

Vance, W. H., Tisdeel, J.M. and McKenzie, B. M. (1998) Residual effects of surface application of organic matter and calcium salts on the sub-soil of a red-brown earth. Australian J. of Experimental Agric. 38, 595-600

Wong, V. N. L., Dalal, R. C., and Greene, R. S. B. (2009) Carbon dynamics of sodic and saline soil following gypsum and organic material additions: A laboratory incubation. Appl. Soil Ecol., 41, 2940. http://dx.doi.org/10.1016/j.apsoil.2008.08.006

Zeng, L. (2004) Response and correlated response to salt tolerance selection in rice by yield parameters. Cereal Res. Communications, 32 (4), 477-484.

Zeng, L. and Shannon, M.C. (2000) Salinity effects on seedling growth and yield components of rice. Crop Sci., 40, 996-1003. https://doi:10.2135/cropsci 2000. 404996x

(Received: 19/12/2017; accepted $: 21 / 2 / 2018$ )

Egypt. J. Soil Sci., 58, No.2 (2018) 


\section{تأثير إضافة بعض محسنات التربة على خواص وإنتاجية الأراضي المتأثرة بالأملاح فى محافظة كفر الثيخ

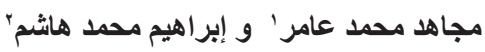

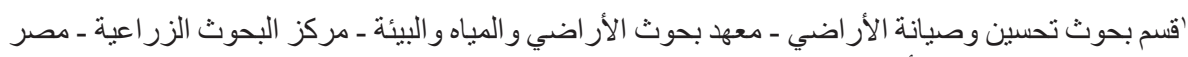

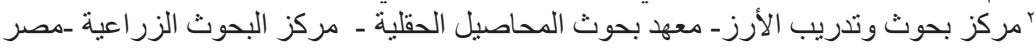

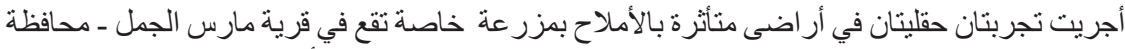

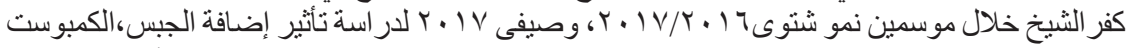

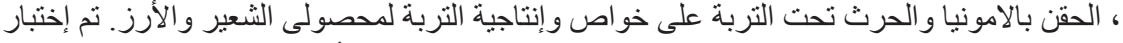

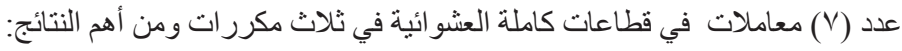

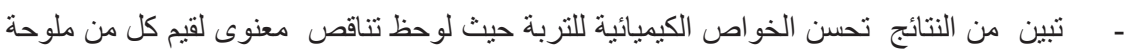

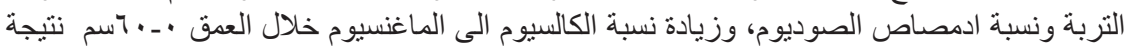

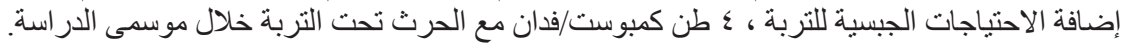

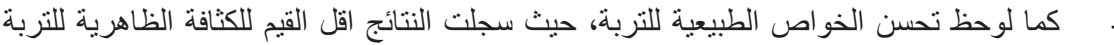
و أعلى قيم للمسامية ،ومعدل الرشح نتيجة اضافة كل من الجبس مع الكمبوست ، و والحرث تحت التربة خلال موسمى الدر اسة.

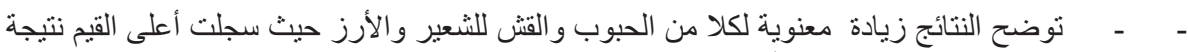
اضافة كل من الجبس و الحقن بالأمونيا مع الحرث من تحت الحت التربة خلال موسمى الدر اسة.

- - - سجل كل من العائد الكلى وصافى العائد وكذلك نسبة العائد على الاستثمار أعلى قيمة نتيجة إضافة

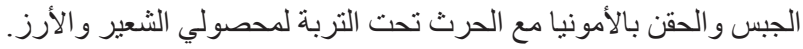

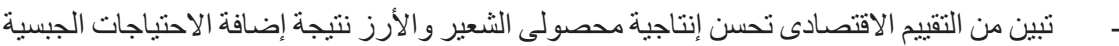

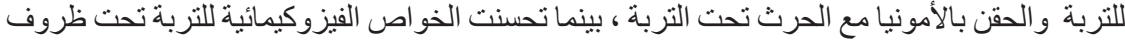

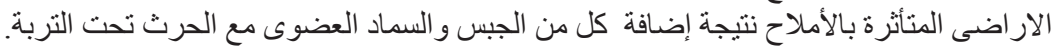

